\title{
Gene transfection in primary stem-like cells of giant cell tumor of bone
}

This article was published in the following Dove Press journal:

Stem Cells and Cloning: Advances and Applications

24 September 2010

Number of times this article has been viewed

\author{
Shalini Singh' \\ Isabella Mak' \\ Patricia Power' \\ Melissa Cunnigham² \\ Robert Turcotte ${ }^{3}$ \\ Michelle Ghert ${ }^{\prime}$ \\ 'Departments of Surgery, ${ }^{2}$ Biology, \\ McMaster University, Hamilton, \\ Ontario; ${ }^{3}$ Department of Orthopaedic \\ Surgery, McGill University Medical \\ Centre, Montreal, Quebec, Canada
}

Correspondence: Michelle Ghert 699 Concession Street, Hamilton, ON, Canada L8V $5 \mathrm{C} 2$

Tel + I 9053879495 ext 64089

Fax + I 9055756343

Email michelle.ghert@jcc.hhsc.ca

\begin{abstract}
The neoplastic stem-like stromal cell of giant cell tumor of bone (GCT) survives for multiple passages in primary culture with a stable phenotype, and exhibits multipotent characteristics. The pathophysiology of this tumor has been studied through the primary culture of these cells. However, successful gene transfer of these cells has not been reported to date. In this short report, we describe the development of the first reported technique that results in efficient gene transfection in primary stem-like cells of GCT.
\end{abstract}

Keywords: gene, transfection, primary cells, TWIST, giant cell tumor

\section{Introduction}

Giant cell tumor of bone (GCT) is a locally aggressive and potentially metastatic bone tumor that occurs in young adults, with a predilection for the weight-bearing regions of the knee. Clinical management involves complete tumor removal and limb reconstruction. ${ }^{1-4}$ Lung metastases are removed surgically because systemic treatment has not been developed for this tumor. ${ }^{5-10}$ Drug development for GCT has thus far focused on inhibiting the osteoclastogenesis that leads to pathologic osteolysis, without specific targeting of the proliferating neoplastic cells. ${ }^{11,12}$

The tumor is comprised of three cellular elements, ie, the multinucleated osteoclastlike giant cell, the monocyte precursor of the giant cells, and the osteoblast-like stromal cell. Reports from our laboratory and several other groups have established the fact that the stromal cell is the proliferating neoplastic element of the tumor. ${ }^{13-15}$ The stromal cell replicates in culture and maintains its phenotype for at least 10 passages, whereas the giant cells die within seven days..$^{14,16-19}$ The stromal cell has been shown to maintain stem cell properties in that it can be induced by exogenous stimulation to develop into more than one mesenchymal phenotype. ${ }^{14}$

Gene transfection of these stem-like cells is essential to develop a deeper understanding of their in vivo behavior and thereby develop targeted systemic treatment. Although Ng et al studied the receptor activator of the nuclear factor kappa B ligand (RANKL) promoter region in GCT stromal cells, all transfection assays in that study were performed on an osteosarcoma cell line. ${ }^{20}$ Here we report transfer of the gene for TWIST, a basic helix-loop-helix (bHLH) transcription factor implicated in the cell lineage of the GCT stem-like stromal cells, which is the first report to date of successful gene transfer of these cells. We believe this is the first step towards identifying targets for systemic therapy that would effectively eliminate the neoplastic processes resulting in the genesis of GCT. 


\section{Methods}

\section{Plasmid construction}

The eGFP-C1 vector was purchased from Clonetech Laboratories (Palo Alto, CA), which contains the green fluorescence protein (GFP) gene under the control of the cytomegalovirus. This empty vector was transformed in DH5 $\alpha$ cells (Invitrogen, Burlington, CA). After plating on kanamycin plates, a clone was sequenced and expended into a $1.5 \mathrm{~L}$ of LB medium for plasmid preparation using a Qiagen Maxi preparation kit (Qiagen, Mississauga, Canada) according to the manufacturer's instructions. TWIST cDNA was obtained from Origene (Rockville, MD) and subcloned into a pDest 51-V5-HIS tag vector (Invitrogen) using the clonase enzyme.

\section{Primary cell line culture}

We established primary cell cultures of GCT stromal tumor cells from fresh GCT tissue obtained from three patients following Ethics Board approval and patient consent. The tissue was processed and maintained in DMEM containing $10 \%$ fetal bovine serum, $2 \mathrm{mM}$ glutamine and $100 \mathrm{U} / \mathrm{mL}$ antibiotics. The resulting cell suspension together with macerated tissue was cultured at $37^{\circ} \mathrm{C}$ in humidified air with $5 \% \mathrm{CO}_{2}$. Following several successive passages, the mesenchymal stromal cells became the homogeneous cell type whereas the multinucleated giant cells were eliminated from the culture. A control immortalized mesenchymal cell line, $\mathrm{KC}$ chondrosarcoma cells, were a generous gift from Dr Joel Block (Rush University, Chicago, IL).

\section{Primary cell transfection}

One day prior to transfection, $1 \times 10^{5}$ cells were plated in each well of a six-well plate containing coverslips to reach approximately $70 \%$ confluency. The transfection was carried out using four different transfection methods, ie, Lipofectamine $^{\mathrm{TM}} 2000$ (Invitrogen), Effectene ${ }^{\circledR}$ (Qiagen), calcium phosphate, and electroporation. Transfection conditions are listed in Table 1. The first three methods were performed according to the manufacturer's instructions and the fourth, electroporation, is described below. All transfection methods of cells studied in this report were repeated 3-5 times on each of three GCT and the KC cell lines. Forty-eight hours post-transfection, cells were examined by fluorescence microscopy. Relative cell viability was measured by plating cells exposed and not exposed to the electric field on parallel plates, allowing them to grow for 72 hours. Relative cell numbers were determined by counting.

\section{Electroporation}

The three GCT and KC cell lines were used for electroporation transfection. Cells were trypsinized and washed with phosphate-buffered saline before transfection. Cells were resuspended into $500 \mu \mathrm{L}$ serum-free media, and $35 \mu \mathrm{g}$ of eGFP-C1 plasmid and TWIST-V5 construct were added separately in $0.4 \mathrm{~cm}$ electroporation cuvettes and kept on ice for 10 minutes. This mixture was electroporated using the Gene Pulser II electroporation apparatus with GCT cells using $700 \mathrm{~V}$ and $50 \mu \mathrm{F}$ capacitance. $\mathrm{KC}$ cell electroporation was conducted at $500 \mathrm{~V}$ and $50 \mu \mathrm{F}$ capacitance. Cells were then plated in chamber slides with supplemental DMEM.

\section{Immunofluorescence assays}

Culture chamber slides were fixed with $4 \%$ paraformaldehyde for 20 minutes at $25^{\circ} \mathrm{C}$, and permeabilized with $0.2 \%$ Triton X-100 for five minutes. Subsequently, these slides were incubated for one hour at $37^{\circ} \mathrm{C}$ with the rabbit polyclonal anti-V5 primary antibody (1:250 dilutions; Abcam, Cambridge, MA). Slides were further incubated in secondary

Table I The quantity of DNA and reagents used and the efficiency of the chemical transfection experiments

\begin{tabular}{|c|c|c|c|c|c|c|c|c|c|c|}
\hline \multirow[t]{2}{*}{ Method } & \multirow[t]{2}{*}{ SN } & \multirow{2}{*}{$\begin{array}{l}\text { DNA } \\
(\mu \mathrm{g})\end{array}$} & \multirow{2}{*}{$\begin{array}{l}\text { Enhancer } \\
(\mu L)\end{array}$} & \multirow{2}{*}{$\begin{array}{l}\text { TR } \\
(\mu \mathrm{L})\end{array}$} & \multirow{2}{*}{$\begin{array}{l}\text { Water } \\
(\mu L)\end{array}$} & \multirow{2}{*}{$\begin{array}{l}\mathrm{CaCl}_{2} \\
(\mu \mathrm{L})\end{array}$} & \multirow{2}{*}{$\begin{array}{l}222 \times \text { HEPES } \\
(\mu \mathrm{L})\end{array}$} & \multirow{2}{*}{$\begin{array}{l}\text { DMEM } \\
(\mathrm{mL})\end{array}$} & \multicolumn{2}{|c|}{ Efficiency (\%) } \\
\hline & & & & & & & & & GCT & KC \\
\hline \multirow[t]{4}{*}{ Effectene } & 1 & 0.4 & 3.2 & 8 & - & - & - & 2 & 0 & 0 \\
\hline & 2 & I & 8 & 16 & - & - & - & 2 & I & 0 \\
\hline & 3 & 2 & 16 & 40 & - & - & - & 2 & - & 20 \\
\hline & 4 & 4 & 20 & 60 & - & - & - & 2 & 10 & 35 \\
\hline \multirow[t]{2}{*}{ Lipofectamine } & 1 & 2 & - & 2 & - & - & - & 3 & 0 & 0 \\
\hline & 2 & 4 & - & 4 & - & - & - & 3 & 0 & 0 \\
\hline \multirow[t]{3}{*}{ Calcium phosphate } & 1 & 2.5 & - & - & 132 & 18.5 & 150 & 2 & 0 & 0 \\
\hline & 2 & 4 & - & - & 215 & 35.5 & 250 & 2 & 0 & 0 \\
\hline & 3 & 8 & - & - & 430 & 61 & 500 & 3 & 0 & 0 \\
\hline
\end{tabular}

Note: For the Effectene transfection kit, I00 $\mu \mathrm{L}$ EC buffer was used for each reaction. DNA was plasmid pEGFPCI.

Abbreviations: $\mathrm{SN}$, serial number; TR, transfection reagent. 
antibody Texas Red conjugated goat antirabbit IgG (1:1000 dilutions; Invitrogen) for one hour at $25^{\circ} \mathrm{C}$. The slides were washed and incubated with DAPI at $25^{\circ} \mathrm{C}$ for three minutes and then mounted using 50\% glycerol.

\section{Real-time reverse transcription- polymerase chain reaction}

RNA was extracted from GCT stromal cells and $\mathrm{KC}$ cells with and without TWIST transfection using RNeasy Mini Kit (Qiagen) according to the manufacturer's instructions. RNA was reverse transcribed into cDNA using the Quanti Tect Reverse Transcription Kit (Qiagen) as per the manufacturer's instructions and employing random hexamers. The real-time polymerase chain reaction (PCR) was performed on a Mini Opticon Real-Time PCR detection system (Bio-Rad Laboratories, Mississauga, Canada) using the iQ SYBR Green Supermix (Bio-Rad). The gene encoding human GAPDH served as an internal control. Cycle threshold $(\mathrm{Ct})$ values were established and the relative change in the expression from GAPDH was determined according to the $2^{-\Delta \Delta C t}$ method of analysis and compared with the expression by TWIST untransfected cells. All experiments were performed in triplicate, and the Student's $t$-test was used to determine statistical significance.

\section{Results}

Transfection efficiency of eGFP and TWIST in KC GCT stromal cells

There was no detectable transfection efficiency in GCT stromal cells or $\mathrm{KC}$ cells with the calcium phosphate and Lipofectamine 2000 methods (data not shown). The Effectene reagent method resulted in high transfection efficiency in the $\mathrm{KC}$ cells, but only $10 \%$ efficiency was observed in the GCT stem-like stromal cells (data not shown). In contrast, substantial transfection efficiency was observed in GCT stromal cells using the electroporation method. Interestingly, $26.8 \%$ transfection efficiency was obtained using the electroporation method in GCT stromal cells using the eGFP empty vector. The GFP expression was observed throughout the cell (Figure 1). Nuclei were stained using DAPI. To facilitate monitoring of the cellular localization

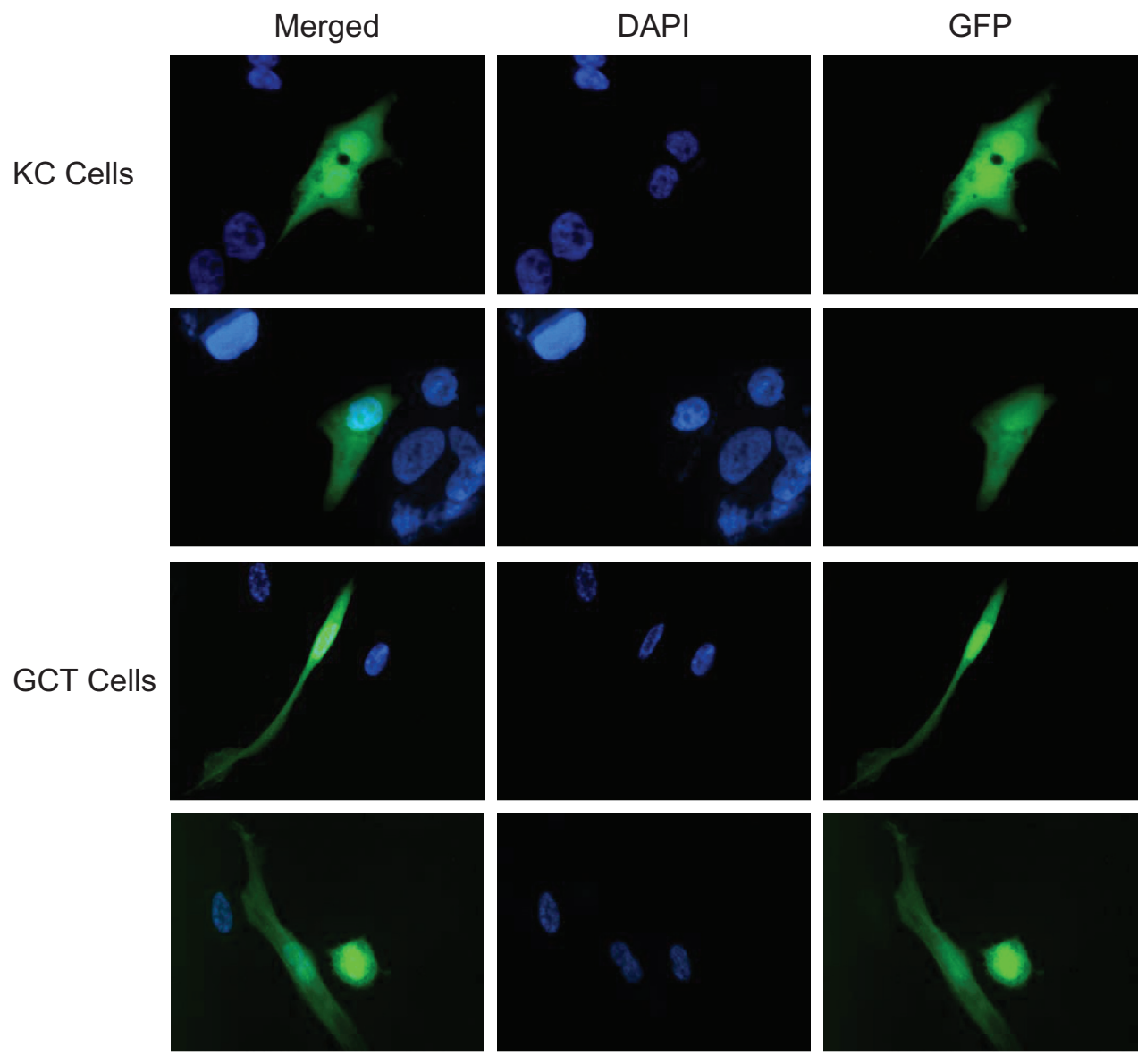

Figure I Green fluorescence protein (GFP) monitored in transfected giant cell tumor of bone stromal and KC cells. Representative immunofluorescence microscopy of KC and GCT-transfected cells with eGFP vector. DAPI staining (blue) indicates the nuclei. (Oil immersion I00× magnification). 
of TWIST, we generated a TWIST-V5-HIS fusion construct and electroporated as described above. Anti-V5 antibody was used to detect the TWIST protein in GCT cells. The recombinant nuclear TWIST protein localized to both the cytoplasm and the nucleus of transiently transfected GCT stromal cells (Figure 2). Transfection efficiencies and anti-V5 localization were similar across all three GCT cell lines.

\section{Quantitation of successful gene transfection}

TWIST expression of untransfected and transfected GCT and $\mathrm{KC}$ cells was determined quantitatively by real-time PCR. Transfection with TWIST upregulated TWIST expression 10 -fold in the GCT cells and sevenfold in the KC cells. Representative data from one GCT cell line and the $\mathrm{KC}$ cell line is shown in Figure 3.

\section{Discussion}

The establishment of primary cell lines from mesenchymal tissue has been reported with the use of human papilloma virus early function genes. ${ }^{21,22}$ The stem-like stromal cells of GCT propagate in culture and maintain their phenotype for several passages and can be studied in vitro in a manner similar to that of established and commercially available cell lines. However, without prior stable viral gene transfection, the GCT cells are resistant to most methods of transient gene transfection. As a result, the upregulation of specific genes in these cells has not been reported to date. This report is the first to describe successful gene transfer in these valuable patient-derived cells.

The lack of previous reports is likely due to the challenges of introducing foreign DNA into mammalian primary cells. Routinely, calcium phosphate, Lipofectamine 2000,

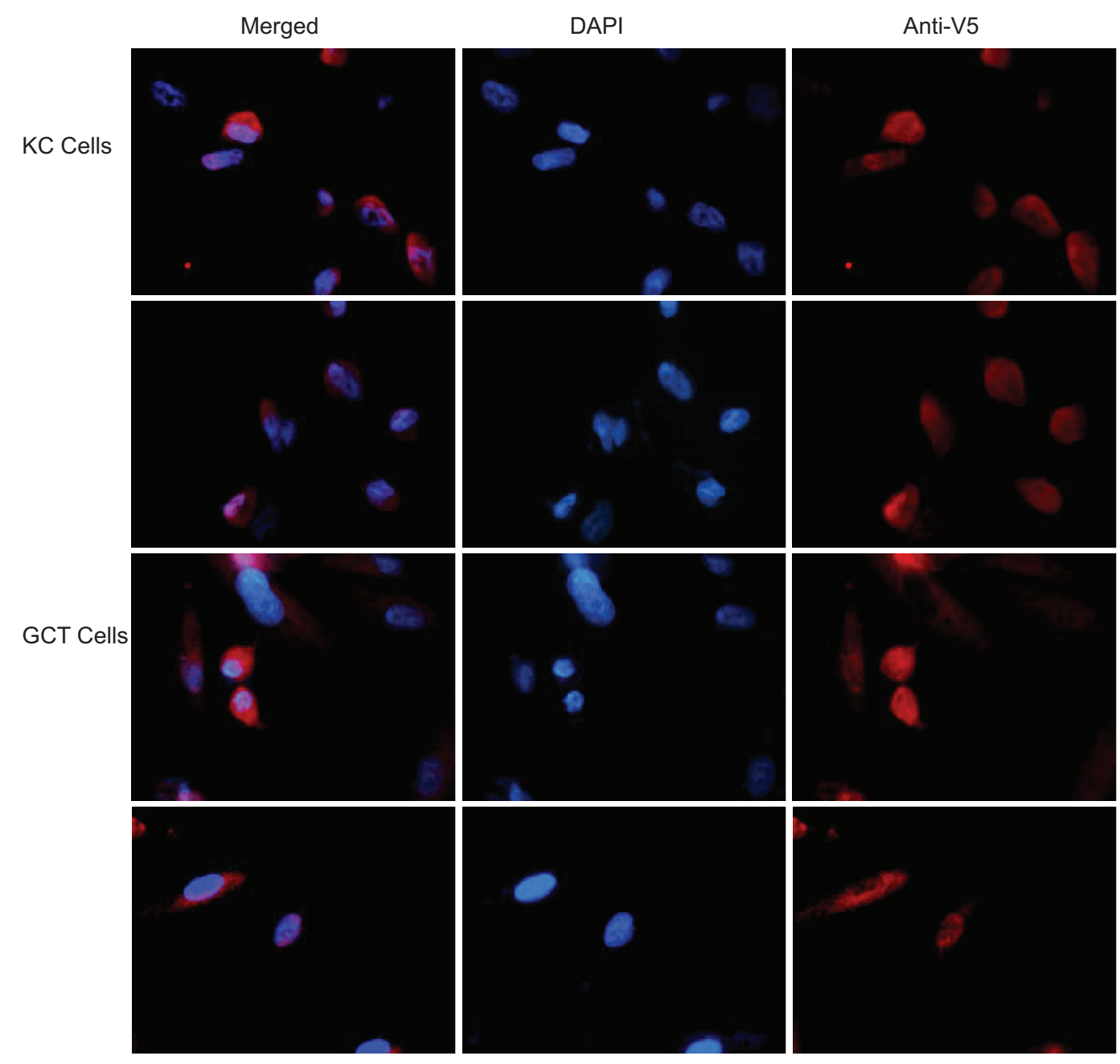

Figure 2 TWIST expression monitored in transfected giant cell tumor of bone stromal and KC cells. Representative immunofluorescence microscopy of KC and giant cell tumor of bone transfected cells with TWIST. DAPI staining (blue) indicates the nuclei. TWIST expression was detected using anti-V5 rabbit polyclonal antibody ( $1: 250$ dilutions, oil immersion 100× magnification). 
A

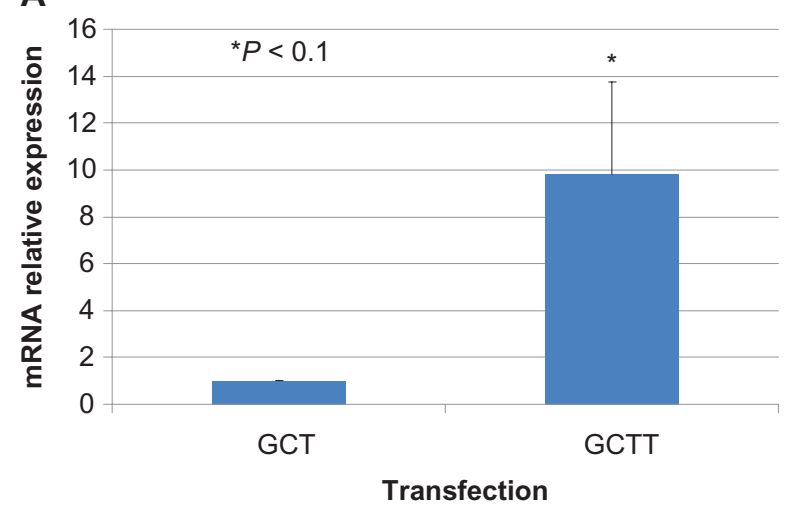

B

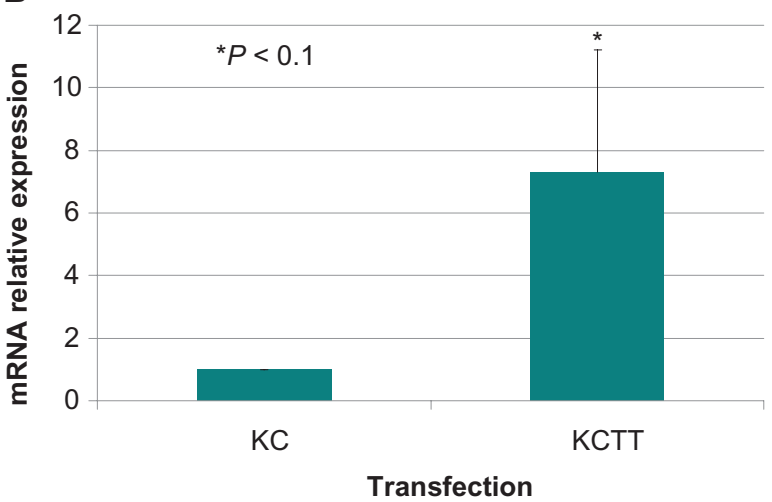

Figure 3 TWIST mRNA expression. A) Real-time polymerase chain reaction of cDNA from giant cell tumor of bone stromal cells representing TWIST upregulation in transfected cells relative to TWIST untransfected cells. B) Quantitative real-time polymerase chain reaction expression of TWIST in TWIST transfected (KCT) and untransfected $(K C)$ KC cells. Results are the average of three replicate experiments.

Effectene, and viral methods have been used in immortalized cell lines. However, transfection using these techniques in the stem-like stromal cells of GCT has thus far been elusive. We found electroporation to be effective, likely due to the fact that it is a physical method of gene delivery and therefore more successful than chemical transfection in these cells that are not specifically designed for in vitro manipulation. Although the electroporation-mediated gene transfer to the GCT cells was successful, this method is limited in its use due to higher cell mortality compared with that of chemical transfection systems.

From a clinical perspective, the stem-like stromal cell of GCT represents the target for antineoplastic drug development, although the nonproliferating osteoclast has been targeted with human monoclonal antibodies to RANKL, with guarded results. ${ }^{23}$ The ability to study these cells and therefore determine the genetic determinants of neoplasia will be greatly enhanced by the development of the method reported herein as the first successful gene transfer of the stem-like stromal cell of GCT. Future studies using this gene transfection method will involve the creation of a stably transfected GFP-tagged cell line which will be used in an animal model of GCT that we are currently developing in order to identify effective targeted therapy for this tumor.

\section{Disclosure}

The authors report no conflicts of interest in this work.

\section{References}

1. Bini SA, Gill K, Johnston JO. Giant cell tumor of bone. Curettage and cement reconstruction. Clin Orthop Relat Res. 1995;321:245-250.
2. Blackley HR, Wunder JS, Davis AM, et al. Treatment of giant-cell tumors of long bones with curettage and bone-grafting. $J$ Bone Joint Surg Am. 1999;81:811-820.

3. Capanna R, Fabbri N, Bettelli G. Curettage of giant cell tumor of bone The effect of surgical technique and adjuvants on local recurrence rate. Chir Organi Mov. 1990;75 Suppl 1:206.

4. Ghert MA, Rizzo M, Harrelson JM, Scully SP. Giant-cell tumor of the appendicular skeleton. Clin Orthop Relat Res. 2002;400: 201-210.

5. Bertoni F, Present D, Sudanese A, Baldini N, Bacchini P, Campanacci M. Giant-cell tumor of bone with pulmonary metastases. Six case reports and a review of the literature. Clin Orthop Relat Res. 1988;237: 275-285.

6. Cheng JC, Johnston JO. Giant cell tumor of bone. Prognosis and treatment of pulmonary metastases. Clin Orthop Relat Res. 1997;338: 205-214.

7. Faisham WI, Zulmi W, Saim AH, et al. Pulmonary metastases of giant cell tumour of the bone. Med J Malaysia. 2004;59 Suppl F: 78-81.

8. Okamoto Y, Mathew S, Daw NC, et al. Giant cell tumor of bone with pulmonary metastases. Med Pediatr Oncol. 2003;41:454-459.

9. Osaka S, Toriyama M, Taira K, Sano S, Saotome K. Analysis of giant cell tumor of bone with pulmonary metastases. Clin Orthop Relat Res. 1997;335:253-261.

10. Siebenrock KA, Unni KK, Rock MG. Giant-cell tumour of bone metastasising to the lungs. A long-term follow-up. J Bone Joint Surg Br. 1998;80:43-47.

11. Chang SS, Suratwala SJ, Jung KM, et al. Bisphosphonates may reduce recurrence in giant cell tumor by inducing apoptosis. Clin Orthop Relat Res. 2004;426:103-109.

12. Tse LF, Wong KC, Kumta SM, et al. Bisphosphonates reduce local recurrence in extremity giant cell tumor of bone: A case-control study. Bone. 2008;42:68-73.

13. Wulling M, Engels C, Jesse N, et al. The nature of giant cell tumor of bone. J Cancer Res Clin Oncol. 2001;127:467-474.

14. Wulling M, Delling G, Kaiser E. The origin of the neoplastic stromal cell in giant cell tumor of bone. Hum Pathol. 2003;34: 983-993.

15. Huang L, Teng XY, Cheng YY, et al. Expression of preosteoblast markers and Cbfa-1 and Osterix gene transcripts in stromal tumour cells of giant cell tumour of bone. Bone. 2004;34:393-401.

16. Ghert M, Simunovic N, Cowan RW, Colterjohn N, Singh G. Properties of the stromal cell in giant cell tumor of bone. Clin Orthop Relat Res. 2007;459:8-13. 
17. Nishimura M, Yuasa K, Mori K, et al. Cytological properties of stromal cells derived from giant cell tumor of bone (GCTSC) which can induce osteoclast formation of human blood monocytes without cell to cell contact. J Orthop Res. 2005;23:979-987.

18. Robinson D, Lewis MM, Nevo Z, et al. The radiographic stage of giant cell tumor related to stromal cells' proliferation. Tissue cultures in 13 cases. Acta Orthop Scand. 1997;68:294-297.

19. Wuelling M, Delling G, Kaiser E. Differential gene expression in stromal cells of human giant cell tumor of bone. Virchows Arch. 2004; 445:621-630.

20. Ng PK, Tsui SK, Lau CP, et al. CCAAT/enhancer binding protein beta is up-regulated in giant cell tumor of bone and regulates RANKL expression. J Cell Biochem. 2010;110:438-446.
21. Kashiwagi $\mathrm{Y}$, Nishitsuka K, Namba H, et al. Cloning and characterization of cell strains derived from human corneal stroma and sclera. Jpn J Ophthalmol. 2010;54:74-80.

22. Grigolo B, Roseti L, Neri S, et al. Human articular chondrocytes immortalized by HPV-16 E6 and E7 genes: Maintenance of differentiated phenotype under defined culture conditions. Osteoarthritis Cartilage. 2002;10:879-889.

23. Thomas D, Henshaw R, Skubitz K, et al. Denosumab in patients with giant-cell tumour of bone: An open-label, phase 2 study. Lancet Oncol. 2010;11:275-280

\section{Publish your work in this journal}

Stem Cells and Cloning: Advances and Applications is an international, peer-reviewed, open access journal. Areas of interest in stem cell research include: Embryonic cell stems; Adult stem cells; Blastocysts; Cordblood stem cells; Stem cell transformation and culture; Therapeutic cloning; Umbilical cord blood and bone marrow cells; Laboratory, animal and human therapeutic studies; Philosophical and ethical issues related to stem cell research. This journal is indexed on CAS. The manuscript management system is completely online and includes a quick and fair peer-review system. Visit http://www.dovepress.com/ testimonials.php to read real quotes from published authors. 